\title{
A randomized double-blind study of testosterone replacement therapy or placebo in testicular cancer survivors with mild Leydig cell insufficiency (Einstein-intervention)
}

Mikkel Bandak ${ }^{1 *}$ (D), Niels Jørgensen ${ }^{2,3}$, Anders Juul ${ }^{2,3}$, Jakob Lauritsen ${ }^{1}$, Michael Kreiberg ${ }^{1}$, Peter Sandor Oturai ${ }^{4}$, Jørn Wulff Helge ${ }^{5}$ and Gedske Daugaard ${ }^{1}$

\begin{abstract}
Background: Elevated serum levels of luteinizing hormone and slightly decreased serum levels of testosterone (mild Leydig cell insufficiency) is a common hormonal disturbance in testicular cancer (TC) survivors. A number of studies have shown that low serum levels of testosterone is associated with low grade inflammation and increased risk of metabolic syndrome. However, so far, no studies have evaluated whether testosterone substitution improves metabolic dysfunction in TC survivors with mild Leydig cell insufficiency.

Methods/design: This is a single-center, randomized, double-blind, placebo-controlled study, designed to evaluate the effect of testosterone replacement therapy in TC survivors with mild Leydig cell insufficiency. Seventy subjects will be randomized to receive either testosterone replacement therapy or placebo. The subjects will be invited for an information meeting where informed consent will be obtained. Afterwards, a 52-weeks treatment period begins in which study participants will receive a daily dose of transdermal testosterone or placebo. Dose adjustment will be made three times during the initial 8 weeks of the study to a maximal daily dose of $40 \mathrm{mg}$ of testosterone in the intervention arm. Evaluation of primary and secondary endpoints will be performed at baseline, 26 weeks post-randomization, at the end of treatment (52 weeks) and 3 months after completion of treatment (week 64).

Discussion: This study is the first to investigate the effect of testosterone substitution in testicular cancer survivors with mild Leydig cell insufficiency. If positive, it may change the clinical handling of testicular cancer survivors with borderline low levels of testosterone.
\end{abstract}

Trial registration: ClinicalTrials.gov: NCT02991209 (November 25, 2016).

Keywords: Testicular cancer, Mild Leydig cell insufficiency, Testosterone substitution

\footnotetext{
*Correspondence: mikkel.bandak@regionh.dk

'Department of Oncology, Copenhagen University Hospital, Rigshospitalet,

2100 Copenhagen, Denmark

Full list of author information is available at the end of the article
}

(c) The Author(s). 2017 Open Access This article is distributed under the terms of the Creative Commons Attribution 4.0 International License (http://creativecommons.org/licenses/by/4.0/), which permits unrestricted use, distribution, and reproduction in any medium, provided you give appropriate credit to the original author(s) and the source, provide a link to the Creative Commons license, and indicate if changes were made. The Creative Commons Public Domain Dedication waiver (http://creativecommons.org/publicdomain/zero/1.0/) applies to the data made available in this article, unless otherwise stated. 


\section{Background}

Testicular cancer (TC) is the most common solid tumour in men between 18 and 35 years of age in developed countries [1], and more than 95\% of patients become long-term survivors [2]. In consequence, a wide range of studies have investigated the prevalence of late effects to TC treatment such as hormonal disturbances [3-5], cardiovascular disease [6-8] and metabolic syndrome [9-12]. The risk of cardiovascular disease is increased in TC patients treated with cisplatin-based chemotherapy when compared to the background population, and it has uniformly been reported that low serum levels of testosterone are associated with increased risk of metabolic syndrome. This has led to the hypothesis that decreased serum levels of testosterone in cancer survivors increase the risk of insulin resistance, metabolic syndrome and long-term risk of cardiovascular disease [13]. Subjective symptoms of testosterone deficiency are decreased libido, decreased level of energy, depressive symptoms, impaired cognitive function and decreased muscle strength while objective signs are decreased bone density, decreased lean body mass, abdominal obesity and anemia [14, 15]. It is well documented that testosterone replacement therapy improves these conditions in patients with manifest testosterone deficiency [16, 17] and numerous studies have demonstrated increased insulin sensitivity, decreased systemic inflammation and recovery of components of the metabolic syndrome [18-20]. However, a substantial proportion of TC survivors are in a compensated state with elevated luteinizing hormone (LH)-levels in combination with borderline low levels of testosterone (mild Leydig cell insufficiency) [21]. To our knowledge, only one study has examined the effects of testosterone replacement therapy in mild Leydig cell insufficiency [22]. This randomized, placebo-controlled study investigated the effect of 12 months of testosterone replacement therapy in 30 long-term survivors of haematological cancer and found a reduction of fatigue and a slight decrease in low density lipoprotein (LDL) cholesterol, and concluded that testosterone substitution should not be recommended in this condition. However, the limit for testosterone replacement therapy was total testosterone $<20 \mathrm{mmol} / \mathrm{L}$ and $\mathrm{LH}>8 \mathrm{IU} / \mathrm{L}$ and the effect on fasting blood glucose, insulin sensitivity and metabolic syndrome was not evaluated.

Thus, the purpose of the present study is to determine whether testosterone replacement therapy improves insulin sensitivity and thus potentially reduces the long-term risk of cardiovascular disease in TC survivors with mild Leydig cell insufficiency after TC treatment.

\section{Methods/design}

\section{Study subjects}

Seventy TC survivors with no relapse $>1$ year since treatment will be included in the study. The main inclusion criteria are serum levels of $\mathrm{LH}>2$ standard deviations (SD) above the age-adjusted mean value and serum levels of free testosterone between 2 SD below the age-adjusted mean value and the age-adjusted mean value. Further inclusion and exclusion criteria are presented in Table 1.

\section{Recruitment and informed consent}

The study flow is presented in Fig. 1. Potential study subjects will be recruited by clinicians during 5-years follow-up after treatment for $\mathrm{TC}$ at the outpatient clinic of Department of Clinical Oncology at Copenhagen University Hospital, Rigshospitalet. Interested patients will be contacted by the study coordinator, who will provide oral and written information about the study. An informed consent form will be signed, when there is a mutual understanding that the subject has understood the information given and still wants to participate. Afterwards, an appointment for screening will be made.

\section{Randomization and procedures for breakage of randomization code}

The 70 study participants will be randomized 1:1 to active treatment or placebo. Randomization will be done

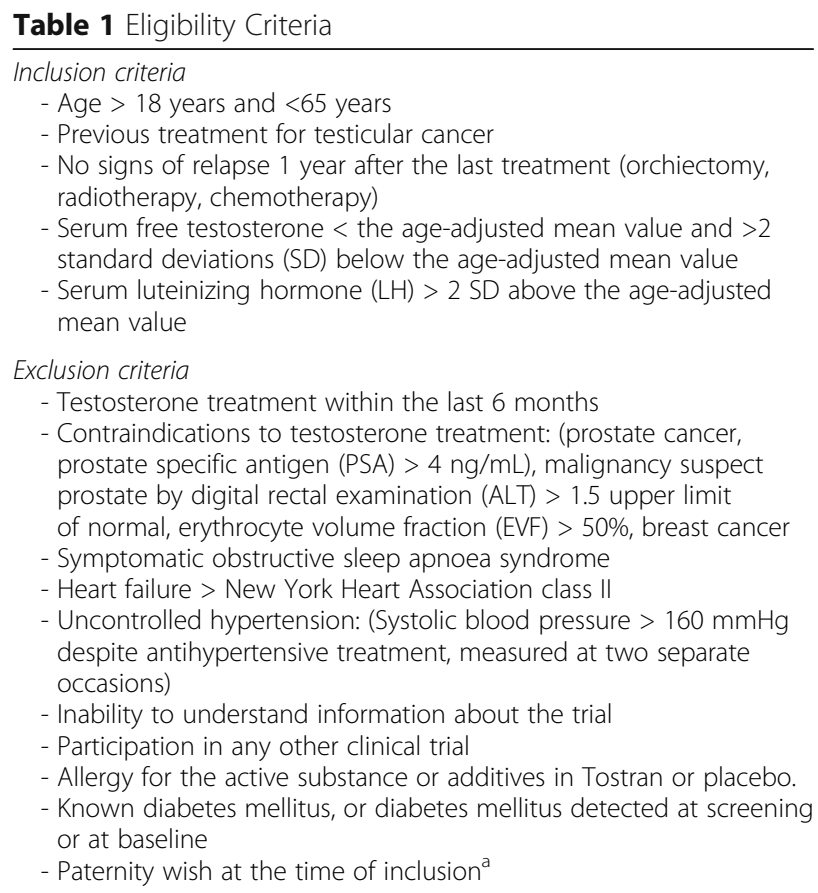

af there is any doubt about paternity wish at the time of inclusion, the study subject should give a semen sample for analysis. If the semen sample shows any viable sperm cells, the study subject will be excluded 


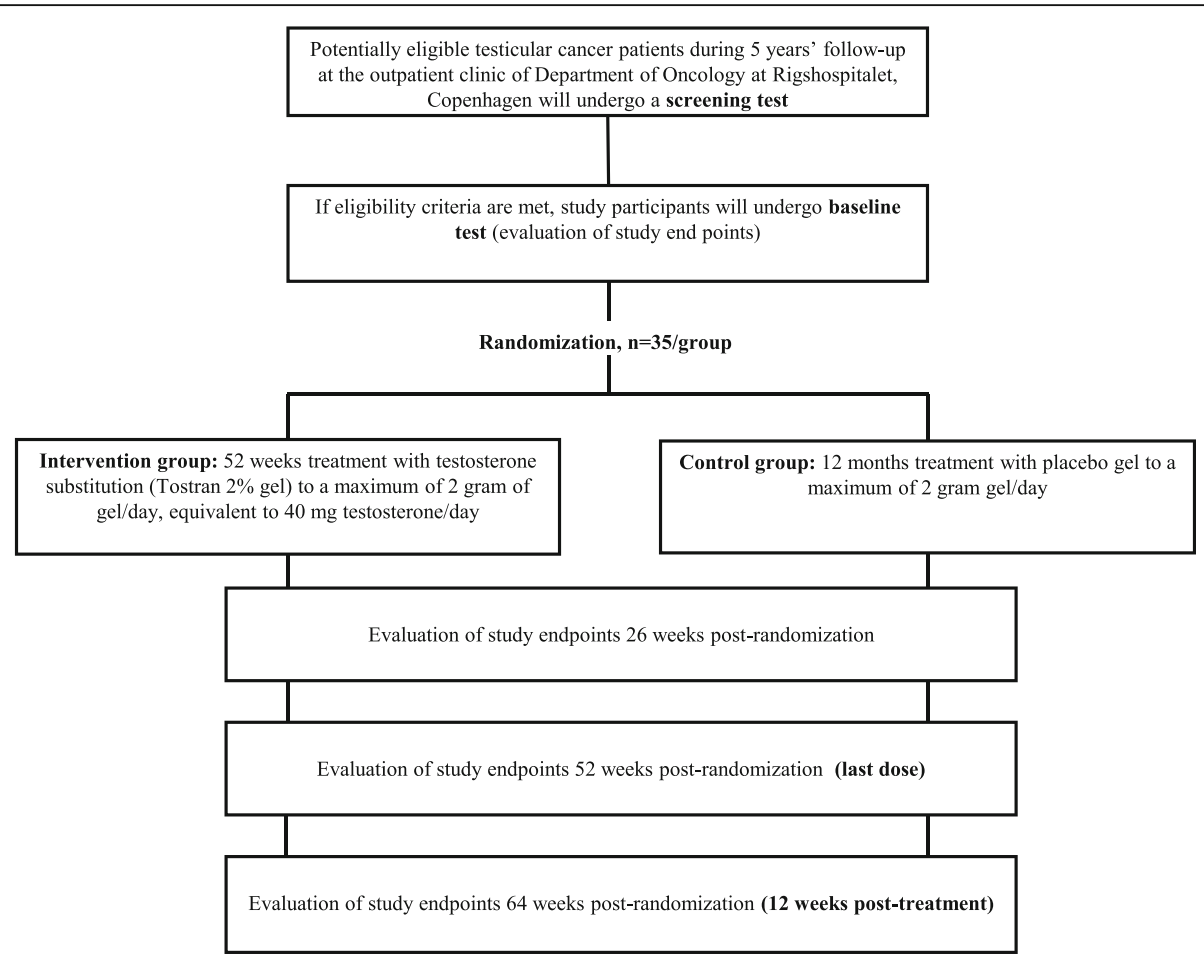

Fig. 1 Study flow diagram

by a web-based randomization tool (http://www.rando mization.com). Each subject will be assigned a specific and unique randomization number. The randomization code will be broken for a subject if a suspected adverse event is judged by the investigators, as serious as it will influence future treatment. The randomization code can be broken at any time during the study period.

\section{Blinding}

Study participants and primary investigators are blinded. An unblinded investigator will evaluate safety issues.

\section{Intervention}

If a subject meets the inclusion criteria, reviewed at the screening and after the baseline investigations, randomization will take place and the study participant will be allocated to treatment with testosterone replacement therapy or placebo. He will initiate treatment the following day in the morning.

Study arm 1: Testosterone (Tostran 2\% gel).

Study participants allocated to active treatment will receive 12 months daily treatment with Tostran $2 \%$ applied transdermally. Dose adjustment will take place three times during the initial 8 weeks to a maximal daily dose of $40 \mathrm{mg}$ (four depressions of the piston) (Table 2).

Study arm 2: Placebo.
Study participants allocated to placebo will receive 12 months daily treatment with placebo. Identical dose adjustment will take place during the initial 8 weeks to four depressions of the piston (Table 2).

The summary of product characteristics of Tostran $2 \%$ can be seen at (http://www.medicines.org.uk/emc/medicine/19702). Placebo contains the same substances as Tostran 2\% except for testosterone.

Tostran 2\% and placebo will be supplied in an identical container labelled with a unique number. Each container has a piston and a depression of the piston delivers $0.5 \mathrm{~g}$ of gel which is equivalent to $10 \mathrm{mg}$ of testosterone in the intervention group.

\section{Dose modifications}

Dose adjustment during the initial 8 weeks and criteria for dose modifications due to safety issues are shown in Table 2. If dose modification due to safety issues is needed, a study participant treated with placebo of the same age or age closest to the study participant who should be dose adjusted will be chosen for identical dose modification to keep the double-blinded study design. If more than one placebo-treated patient is at the same age, the subject with a BMI closest to the study participant who should be dose-adjusted will be chosen for identical dose modification. 
Table 2 Dose adjustments and dose modifications due to safety issues

\begin{tabular}{|c|c|c|}
\hline Dose adjustment & Dose modifications & Follow-up \\
\hline \multicolumn{3}{|l|}{$\begin{array}{l}\text { Starting dose: } 10 \mathrm{mg} \text { daily } \\
\text { (one depression of the piston) }\end{array}$} \\
\hline \multicolumn{3}{|l|}{$\begin{array}{l}\text { Week 2: } 20 \mathrm{mg} \text { daily } \\
\text { (two depressions of the piston) }\end{array}$} \\
\hline \multicolumn{3}{|l|}{$\begin{array}{l}\text { Week 4: } 30 \text { mg daily } \\
\text { (three depressions of the piston) }\end{array}$} \\
\hline \multicolumn{3}{|l|}{$\begin{array}{l}\text { Week 8: } 40 \text { mg daily } \\
\text { (four depressions of the piston) }\end{array}$} \\
\hline \multicolumn{3}{|l|}{52 weeks: End of treatment } \\
\hline \multicolumn{3}{|l|}{ Safety issues } \\
\hline $\begin{array}{l}\text { Increase in free testosterone to }>3 \text { SD } \\
\text { above the age-adjusted mean }\end{array}$ & Dose adjustment to previous treatment step & $\begin{array}{l}\text { Measurement of free testosterone and LH after } \\
14 \text { days and dose adjustment accordingly }\end{array}$ \\
\hline $\begin{array}{l}\text { Decrease in } \mathrm{LH} \text { to }<-2 \mathrm{SD} \text { below the } \\
\text { age-adjusted mean }\end{array}$ & Dose adjustment to previous treatment step & $\begin{array}{l}\text { Measurement of free testosterone and LH after } \\
14 \text { days and dose adjustment accordingly }\end{array}$ \\
\hline Increase in EVF to $>52 \%$ & Dose adjustment to previous treatment step & $\begin{array}{l}\text { Measurement of EVF after } 14 \text { days and dose } \\
\text { adjustment accordingly }\end{array}$ \\
\hline $\begin{array}{l}\text { Plasma PSA }>4 \mathrm{ng} / \mathrm{mL} \text { at any visit. A PSA } \\
\text { increase of }>1 \mathrm{ng} / \mathrm{mL} \text { at visit } 7 \text { or visit } 8, \\
\text { using plasma PSA at visit } 6 \text { as baseline }\end{array}$ & Referral for urological consultation & $\begin{array}{l}\text { According to urological consultation: Stop } \\
\text { treatment if increased risk of prostate cancer. } \\
\text { Continue treatment at the same treatment step } \\
\text { if there is no increased risk of prostate cancer }\end{array}$ \\
\hline $\begin{array}{l}\text { An increase in systolic blood pressure } \\
>20 \mathrm{mmHg} \text { confirmed at two separate } \\
\text { measurements despite antihypertensive } \\
\text { therapy, if not due to free testosterone } \\
\text { being }>3 \text { SD from the age-adjusted mean }\end{array}$ & Stop treatment & $\begin{array}{l}\text { Measurement of blood pressure after } 14 \text { days. } \\
\text { If still elevated referral to general practitioner }\end{array}$ \\
\hline ALT increase $>1.5$ upper reference level & Stop treatment & $\begin{array}{l}\text { Measurement of ALT after } 14 \text { days. If } \\
\text { still elevated referral for hepatological } \\
\text { consultation }\end{array}$ \\
\hline $\begin{array}{l}\text { Any other exclusion criteria becoming } \\
\text { apparent during treatment }\end{array}$ & Stop treatment & \\
\hline
\end{tabular}

\section{Planned inclusion}

It is estimated that 70 study participants will be included by the end of 2018 .

\section{Measurements}

The schedule for data assessment is presented in Table 3 and the study endpoints are presented in Table 4.

A human chorionic gonadotropin (hCG) stimulation test will be done at the screening visit in order to evaluate the residual capacity of the remaining testicle in the included study participants: After blood sampling, where serum testosterone is analysed, 5000 IU of hCG is injected intramuscularly. Blood samples are drawn $72 \mathrm{~h}$ after the administration of hCG for evaluation of serum testosterone.

Study endpoints will be evaluated at baseline (before randomization), 26 weeks post-randomization, 52 weeks post-randomization (last dose) and 64 weeks postrandomization (12 weeks after last dose). Participants will arrive at the hospital after an overnight fast (minimum $8 \mathrm{~h}$ ) at visits where study endpoints will be evaluated.

\section{Primary outcome}

The primary endpoint is insulin sensitivity expressed as the $2 \mathrm{~h}$ change in blood glucose ( $\Delta 2 \mathrm{~h}$ glucose) evaluated by oral glucose tolerance test: Fasting blood samples will be drawn where plasma glucose and insulin are analysed. Afterwards, at time zero, 75 g glucose will be administered orally after being dissolved in 250-300 ml water. Plasma glucose and insulin will be analysed again after $2 \mathrm{~h}$.

\section{Secondary outcomes}

Evaluation of each component of metabolic syndrome (waist circumference, blood pressure, fasting plasma glucose, plasma HDL-cholesterol and plasma triglycerides) as well as presence of metabolic syndrome ( $\geq 3$ components) will be assessed according to the International Diabetes Federation criteria [23]. Waist circumference and hip circumference will be measured according to guidelines from World Health Organization [24] and blood pressure will be determined twice with an automatic device after 5 min rest. 
Table 3 Data Assessment Schedule

\begin{tabular}{|c|c|c|c|c|c|c|c|c|}
\hline Data assessment & Screening & $\begin{array}{l}\text { Baseline } \\
\text { Week } 0\end{array}$ & $\begin{array}{l}\text { Dose adjustment } 1 \\
\text { Week } 2\end{array}$ & $\begin{array}{l}\text { Dose adjustment } 2 \\
\text { Week } 4\end{array}$ & $\begin{array}{l}\text { Dose adjustment } 3 \\
\text { Week } 8\end{array}$ & $\begin{array}{l}\text { On treatment } \\
\text { Week } 26\end{array}$ & $\begin{array}{l}\text { Last dose } \\
\text { Week } 52\end{array}$ & $\begin{array}{l}\text { Follow-up } \\
\text { Week } 64\end{array}$ \\
\hline hCG-stimulation test & $x$ & & & & & & & \\
\hline Blood pressure & $x$ & $x$ & $x$ & $x$ & $x$ & $x$ & $x$ & $x$ \\
\hline Blood samples & $x$ & $x$ & $x$ & $x$ & $x$ & $x$ & $x$ & $x$ \\
\hline Waist circumference & & $x$ & & & & $x$ & $x$ & $x$ \\
\hline DXA scan & & $x$ & & & & $x$ & $x$ & $x$ \\
\hline Oral glucose tolerance test & & $x$ & & & & $x$ & $x$ & $x$ \\
\hline Questionnaires & & $x$ & & & & $x$ & $x$ & $x$ \\
\hline Anogenital distance & & $x$ & & & & & $x$ & \\
\hline Randomization & & $x$ & & & & & & \\
\hline On treatment & & $x$ & $x$ & $x$ & $x$ & $x$ & $x$ & \\
\hline Dose adjustment & & & $x$ & $x$ & $x$ & & & \\
\hline Evaluation of side effects & & $x$ & $x$ & $x$ & $x$ & $x$ & $x$ & $x$ \\
\hline
\end{tabular}

Plasma samples for analysis of inflammatory markers: tumor necrotic factor-alpha (TNF-alpha), interleukine (IL)$1 \beta$, IL-6 and IL-10 as well as adipocytokines (adiponectin and leptin) will be processed and stored at $-80 \mathrm{C}^{\circ}$ for batch analysis after completion of the study. Inflammatory markers will be analysed by MesoScaleDiscovery multiplex (MesoScaleDiscovery, USA) while leptin will be analysed by immunoassay and adiponectin by radioimmunoassay.

Total plasma cholesterol, HDL-cholesterol, LDLcholesterol, plasma glucose, haemoglobin A1c and plasma

Table 4 Study Endpoints

Systemic effects
- Glucose metabolism (fasting glucose, 2 h glucose, insulin,
hemoglobin a1c, HOMA-index)
- Cholesterol (high density lipoprotein-cholesterol, low density
lipoprotein-cholesterol, total cholesterol)
- Inflammatory markers (interleukin 1- $\beta$, interleukin-6, interleukin-8,
tumour necrotic factor-alpha)
- Adipocytokines (adiponectin, leptin)
- Reproductive hormones (total testosterone, free testosterone,
luteinizing hormone)
Body composition and bone mineral density
- Whole body bone mineral density, whole body t-score, t-score of
the lumbar spine and proximal femoral bone
- Lean body mass
- Whole body fat percent (Z-score)
- Visceral adiposity, android fat distribution, gynoid fat distribution
Anthropomorphic measures
- Waist circumference
- Hip circumference
- Body mass index
- Anogenital distance
Patient reported outcomes
- Health related quality of Life (EORTC QLQ-C30)
- Anxiety and Depression: (Hospital Depression and Anxiety Scale)
- Fatigue: (Multiple Fatigue Inventory-20)
- Symptoms of testosterone deficiency and erectile dysfunction:
(International Index of Erectile Function-15)

Abbreviations: HOMA-index Homeostasis model assessment index, EORTC QLQC30 European Organization for Research and Treatment of Cancer Quality of Life Questionnaire insulin will be measured using standard laboratory procedures. Homeostasis Model Assessment index will be calculated as described in [25].

Serum total testosterone and free testosterone will be analysed by liquid chromatography-mass spectrometry and LH will be analysed by time-resolved immunofluorometric assay (Delfia; Perkin Elmer, Turku, Finland),

Body composition and bone mineral density will be assessed by whole body Dual-energy X-ray absorptiometry (DXA-scan) performed on a Lunar Prodigy Advance Scanner (GE Healthcare, Madison, WI; software package Encore v. 16). Whole body bone mineral density (BMD) will be determined, as well as BMD of the lumbar spine and proximal femoral bone. Lean body mass, whole body fat percent, and visceral fat mass will be determined.

Anogenital distance will be measured in supine position with the legs abducted allowing the soles of the feet to meet as described in [26]. The anogenital distance will be measured at baseline and 52 months post-randomization using a digital caliper.

Patient reported outcomes will be assessed by standardized questionnaires: Quality of life (EORTC QLQ-30) [27], fatigue (Multiple Fatigue Inventory) [28], symptoms of testosterone deficiency and erectile dysfunction (International Index of Erectile Dysfunction) (IIEF-15) [29] and depression and anxiety (Hospital Anxiety and Depression Scale) (HADS) [30].

EORTC QLQ-30 consists of nine symptom scales, five function scales, and a global health/quality of life scale. A high score on the symptom scales indicates a high symptom burden while a high score on the function scales and global function scale indicates lower symptom burden. MFI-20 is covering five domains of fatigue: general fatigue, physical fatigue, reduced activity, reduced motivation and mental fatigue. A higher score on each 
of the five scales indicates more fatigue. HADS consists of two subscales covering anxiety and depression. A higher score on each scale indicates higher symptom burden. IIEF-15 examines the five main domains of male sexual function: Erectile function, orgasmic function, sexual desire, overall satisfaction and intercourse satisfaction. A lower score indicates higher symptom burden.

Additionally, study participants will be asked about medication, tobacco consumption, alcohol consumption and level of physical activity.

\section{Adverse events}

Presence of side effects according to common toxicity criteria version 4.0 (https://evs.nci.nih.gov/ftp1/CTCAE/ CTCAE_4.03_2010-06-14_QuickReference_5x7.pdf) will be evaluated at each visit and documented in case report forms.

\section{Sample size}

It is expected that 30 study participants in each arm will complete the study to week 52 . A power calculation has been conducted and with 30 study participants in each arm, there is $80 \%$ power to show a $0.5 \mathrm{mmol}$ difference in $\Delta 2 \mathrm{~h}$ glucose between baseline and 52 weeks between the two arms. The significance level is set at $5 \%$.

\section{Analytic plan}

Changes in continuous outcomes between baseline and 52 weeks will be compared between the investigational group and placebo group with independent samples $t$-test. Changes in prevalence of metabolic syndrome components and metabolic syndrome between baseline and 52 weeks will be compared with chi-square test. Changes in patient reported outcomes and adverse events between baseline and 52 weeks will be compared with Mann-Whitney U-test. As an additional analysis outcomes in the intervention arm will be compared with independent samples t-test and chi-square test between study participants who had an adequate response to the hCG stimulation test performed at the screening visit and those who had and inadequate response.

\section{Discussion}

Testosterone substitution is currently advocated in men with evident biochemical testosterone deficiency measured on $>1$ occasion in concordance with clinical signs and symptoms of testosterone deficiency in the general population [31]. Mild Leydig cell insufficiency is a common condition in testicular cancer survivors, and it has not been clarified whether testosterone substitution is of potential benefit in this population. The results of the present study might have the potential to change the clinical handling of testicular cancer survivors with mild
Leydig cell insufficiency in order to decrease the longterm risk of cardiovascular disease.

Recruitment of study participants began in November 2016. By the end of January 2017, approximately 60 potential study participants have received information about the study of which 22 have signed informed consent and been through screening examinations. The most common reason for not wanting to participate in the study after having received information has been that potential study participants found the study too time consuming. Fear of adverse effects to testosterone treatment has been the second most common reason for non-paticipation.

Ten of the 22 screened study participants have so far been randomized, four are in line for randomization while there have been eight screening failures.

As testosterone and LH show considerable day -today variation [32] screening failures would be expected. It should, however, be emphasized that all study participants who are undergoing screening examinations have experienced elevated serum LH levels in combination with borderline low serum testosterone at a previous point in time. Accordingly, inclusion in this study is based on at least two measurements of elevated $\mathrm{LH}$ and borderline low testosterone levels.

In conclusion, the results of this study will provide evidence for the clinical handling of TC survivors with mild Leydig cell insufficiency and potentially improve morbidity and quality of life in this subgroup of cancer survivors.

\section{Abbreviations \\ Einstein: Early INtervention with teSTostErone IN in testicular cancer survivors; HDL-cholesterol: High density lipoprotein cholesterol; LDL-cholesterol: Low density lipoprotein cholesterol; LH: Luteinizing Hormone; SD: Standard deviation; TC: Testicular cancer}

\section{Acknowledgements \\ No other contributions are considered.}

\section{Funding}

Expenses will be paid by the Department of Oncology, Copenhagen University Hospital, Rigshospitalet. Kiowa Kirin International will cover expenses for Tostran and placebo. The Danish Cancer Society, The Danish Cancer Research Foundation and Rigshospitalet have supported the study.

Availability of data and materials

Once data has been obtained, analysed and published it will be made available.

\section{Authors' contributions}

$M B, N J, A J, P S$ and GD developed the study concept and protocols. Primary investigator MB will implement the protocol with MK and NJ. MB drafted the manuscript; all authors contributed to revision and approval of the final manuscript.

\section{Ethics approval and consent to participate}

The study has been approved by the Regional Ethics committee for the Capital Region of Denmark (Protocol nr: H-15008901), the Danish Data Protection Agency (j.nr:2012-58-0004) and The Danish Health Authorities (EudraCT-number 2015-001452-30). The study will be monitored and 
quality assured by the Unit for Good Clinical Practice (GCP) at Copenhagen University Hospital.

All eligible participants will receive thorough oral and written information about the study. Study participants will be informed that they are free to drop out of the study at any time without consequence, and that their data may still be used in the analysis. All participants should provide a signed consent form before entering the study.

\section{Consent for publication}

All eligible participants will be explained that individual data will be pseudoanonymized, and stored in a password-protected device only accessed by the researchers.

\section{Competing interests}

The authors declare that they have no competing interests.

\section{Author details}

'Department of Oncology, Copenhagen University Hospital, Rigshospitalet, 2100 Copenhagen, Denmark. ${ }^{2}$ Department of Growth and Reproduction, Copenhagen University Hospital, Rigshospitalet, Copenhagen, Denmark. ${ }^{3}$ International Center for Research and Research Training in Endocrine Disruption of Male Reproduction and Child Health (EDMaRC), University of Copenhagen, Copenhagen, Denmark. ${ }^{4}$ Department of Clinical Physiology, Nuclear Medicine and PET, Copenhagen University Hospital, Rigshospitalet, Copenhagen, Denmark. ${ }^{5}$ Department of Biomedical Sciences, University of Copenhagen, Copenhagen, Denmark.

\section{Received: 13 February 2017 Accepted: 26 June 2017}

Published online: 03 July 2017

\section{References}

1. Ferlay J, Shin H-R, Bray F, Forman D, Mathers C, Parkin DM. Estimates of worldwide burden of cancer in 2008: GLOBOCAN 2008. Int J Cancer [Internet]. 2010 [cited 2016 Oct 23]; 127:2893-917. Available from: http:// www.ncbi.nlm.nih.gov/pubmed/21351269.

2. Verdecchia A, Francisci S, Brenner H, Gatta G, Micheli A, Mangone L, et al. Recent cancer survival in Europe: a 2000-02 period analysis of EUROCARE-4 data. Lancet Oncol. [Internet]. 2007 [cited 2016 Sep 8];8:784-96. Available from: http://www.ncbi.n/m.nih.gov/pubmed/17714993.

3. Nord C, Bjøro T, Ellingsen D, Mykletun A, Dahl O, Klepp O, et al. Gonadal hormones in long-term survivors 10 years after treatment for unilateral testicular cancer. Eur Urol. [Internet]. 2003 [cited 2013 Mar 27];44:322-8. Available from: http://dx.doi.org/10.1016/S0302-2838(03)00263-X.

4. Wiechno P, Demkow T, Kubiak K, Sadowska M, Kamińska J. The quality of life and hormonal disturbances in testicular cancer survivors in Cisplatin era. Eur Urol. [Internet]. 2007 [cited 2016 Aug 18];52:1448-54. Available from: http://www.ncbi.nlm.nih.gov/pubmed/17544206.

5. Sprauten M, Brydøy M, Haugnes HS, Cvancarova M, Bjøro T, Bjerner J, et al. Longitudinal serum testosterone, luteinizing hormone, and folliclestimulating hormone levels in a population-based sample of long-term testicular cancer survivors. J Clin Oncol. [Internet]. 2014 [cited 2016 Apr 21]; 32:571-8. Available from: http://www.ncbi.nlm.nih.gov/pubmed/24419125.

6. van den Belt-Dusebout AW, Nuver J, de Wit R, Gietema JA, ten Bokkel Huinink WW, Rodrigus PTR, et al. Long-term risk of cardiovascular disease in 5-year survivors of testicular cancer. J Clin Oncol. [Internet]. 2006 [cited 2017 Jan 3];24:467-75. Available from: http://www.ncbi.nlm.nih.gov/pubmed/ 16421423.

7. Meinardi MT, Gietema JA, van der Graaf WT, van Veldhuisen DJ, Runne MA, Sluiter WJ, et al. Cardiovascular morbidity in long-term survivors of metastatic testicular cancer. J Clin Oncol. [Internet]. 2000 [cited 2013 Apr 8]; 18:1725-32. Available from: http://www.ncbi.nlm.nih.gov/pubmed/ 10764433.

8. Huddart RA, Norman A, Shahidi M, Horwich A, Coward D, Nicholls J, et al. Cardiovascular disease as a long-term complication of treatment for testicular cancer. J Clin Oncol. [Internet]. 2003 [cited 2013 Apr 1];21:1513-23. Available from: http://www.ncbi.nlm.nih.gov/pubmed/12697875.

9. Haugnes HS, Aass N, Fosså SD, Dahl O, Klepp O, Wist EA, et al. Components of the metabolic syndrome in long-term survivors of testicular cancer. Ann Oncol. [Internet]. 2007 [cited 2013 Apr 4];18:241-8. Available from: http:// www.ncbi.nlm.nih.gov/pubmed/17060482.
10. Nuver J, Smit AJ, Wolffenbuttel BHR, Sluiter WJ, Hoekstra HJ, Sleijfer DT, et al. The metabolic syndrome and disturbances in hormone levels in longterm survivors of disseminated testicular cancer. J Clin Oncol. [Internet]. 2005 [cited 2013 Apr 8];23:3718-25. Available from: http://www.ncbi.nlm.nih. gov/pubmed/15738540.

11. de Haas EC, Altena R, Boezen HM, Zwart N, Smit a J, Bakker SJL, et al. Early development of the metabolic syndrome after chemotherapy for testicular cancer. Ann Oncol. [Internet]. 2013;24:749-55. Available from: http://www. ncbi.nlm.nih.gov/pubmed/23131388.

12. Willemse PM, Burggraaf J, Hamdy N a T, Weijl NI, Vossen CY, van Wulften L, et al. Prevalence of the metabolic syndrome and cardiovascular disease risk in chemotherapy-treated testicular germ cell tumour survivors. Br J Cancer [Internet]. 2013;109:60-7. Available from: http://www.ncbi.nIm.nih.gov/ pubmed/23660945.

13. de Haas EC, Oosting SF, Lefrandt JD, Wolffenbuttel BH, Sleiffer DT, Gietema JA. The metabolic syndrome in cancer survivors. Lancet Oncol. 2010;11:193-203.

14. Howell S, Shalet S. Testosterone deficiency and replacement. Horm. Res. [Internet]. 2001 [cited 2013 Apr 8];56 Suppl 1:86-92. Available from: http:// www.ncbi.nlm.nih.gov/pubmed/11786693.

15. Zitzmann M, Nieschlag E. Hormone substitution in male hypogonadism. Mol Cell Endocrinol. [Internet]. 2000 [cited 2013 Apr 8];161:73-88. Available from: http://www.ncbi.nlm.nih.gov/pubmed/10773395.

16. Bhasin S, Storer TW, Berman N, Yarasheski KE, Clevenger B, Phillips J, et al. Testosterone replacement increases fat-free mass and muscle size in hypogonadal men. J Clin Endocrinol Metab. 1997:82:407-13.

17. Snyder PJ, Peachey H, Berlin JA, Hannoush P, Haddad G, Dlewati A, et al. Effects of testosterone replacement in hypogonadal men. J Clin Endocrinol Metab. 2000;85(8):2670-7.

18. Kapoor D, Clarke S, Stanworth R, Channer KS, Jones TH. The effect of testosterone replacement therapy on adipocytokines and C-reactive protein in hypogonadal men with type 2 diabetes. Eur J Endocrinol. 2007;156(5):595-602.

19. Kalinchenko SY, Tishova YA, Mskhalaya GJ, Gooren LJG, Giltay EJ, Saad F. Effects of testosterone supplementation on markers of the metabolic syndrome and inflammation in hypogonadal men with the metabolic syndrome: the double-blinded placebo-controlled Moscow study. Clin Endocrinol. 2010;73:602-12.

20. Malkin CJ, Pugh PJ, Jones RD, Kapoor D, Channer KS, Jones TH. The effect of testosterone replacement on endogenous inflammatory cytokines and lipid profiles in hypogonadal men. J Clin Endocrinol Metab. 2004;89(7):3313-8.

21. Bandak M, Aksglaede L, Juul A, Rørth M, Daugaard G. The pituitary-Leydig cell axis before and after orchiectomy in patients with stage I testicular cancer. Eur J Cancer. 2011:47:2585-91.

22. Howell SJ, Radford JA, Adams JE, Smets EMA, Warburton R, Shalet SM Randomized placebo-controlled trial of testosterone replacement in men with mild Leydig cell insufficiency following cytotoxic chemotherapy. Clin Endocrinol. 2001;55:315-24.

23. Alberti KGMM, Zimmet P, Shaw J. The metabolic syndrome-a new worldwide definition. Lancet (London, England) [Internet]. 2015 [cited 2016 Aug 25];366:1059-62. Available from: http://www.ncbi.nlm.nih.gov/pubmed/ 16182882.

24. WHO. Waist Circumference and Waist-Hip Ratio: Report of a WHO Expert Consultation. Geneva: World Health; 2008. p. 8-11.

25. Matthews DR, Hosker JP, Rudenski AS, Naylor BA, Treacher DF, Turner RC. Homeostasis model assessment: insulin resistance and $\$ \beta \$$-cell function from fasting plasma glucose and insulin concentrations in man. Diabetologia [Internet]. 1985;28:412-9. Available from: http://dx.doi.org/10. 1007/BF00280883.

26. Eisenberg ML, Hsieh MH, Walters RC, Krasnow R, Lipshultz LI. The relationship between anogenital distance, fatherhood, and fertility in adult men. Plos One [Internet]. 2011 [cited 2017 Jan 13];6:e18973. Available from: http://www.pubmedcentral.nih.gov/articlerender.fcgi?artid=3092750\&tool= pmcentrez\&rendertype=abstract

27. Kaasa S, Bjordal K, Aaronson N, Moum T, Wist E, Hagen S, et al. The EORTC core quality of life questionnaire (QLQ-C30): validity and reliability when analysed with patients treated with palliative radiotherapy. Eur J Cancer [Internet]. 1995 [cited 2016 Mar 22];31A:2260-3. Available from: http://www. ncbi.nlm.nih.gov/pubmed/8652253.

28. Smets EM, Garssen B, Bonke B, De Haes JC. The multidimensional fatigue Inventory (MFI) psychometric qualities of an instrument to assess fatigue. J Psychosom Res. [Internet]. 1995 [cited 2017 Jan 13];39:315-25. Available from: http://www.ncbi.nlm.nih.gov/pubmed/7636775. 


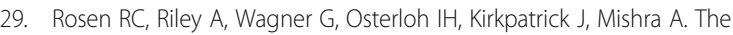
international index of erectile function (IIEF): a multidimensional scale for assessment of erectile dysfunction. Urology [Internet]. 1997 [cited 2017 Jan 13];49:822-30. Available from: http://www.ncbi.n/m.nih.gov/pubmed/ 9187685.

30. Zigmond AS, Snaith RP. The hospital anxiety and depression scale. Acta Psychiatr Scand. [Internet]. 1983 [cited 2017 Jan 13];67:361-70. Available from: http://www.ncbi.nlm.nih.gov/pubmed/6880820.

31. Bhasin S, Cunningham GR, Hayes FJ, Matsumoto AM, Snyder PJ, Swerdloff $R S$, et al. Testosterone therapy in men with androgen deficiency syndromes: an Endocrine Society clinical practice guideline. J Clin Endocrinol Metab. [Internet]. 2010 [cited 2015 Feb 26];95:2536-59. Available from: http://www. ncbi.nlm.nih.gov/pubmed/20525905.

32. Brambilla DJ, O'Donnell AB, Matsumoto AM, McKinlay JB. Intraindividual variation in levels of serum testosterone and other reproductive and adrenal hormones in men. Clin Endocrinol. [Internet]. 2007 [cited 2017 Feb 6];67:853-62. Available from: http://www.ncbi.n/m.nih.gov/pubmed/ 18052942.

\section{Submit your next manuscript to BioMed Central} and we will help you at every step:

- We accept pre-submission inquiries

- Our selector tool helps you to find the most relevant journal

- We provide round the clock customer support

- Convenient online submission

- Thorough peer review

- Inclusion in PubMed and all major indexing services

- Maximum visibility for your research

Submit your manuscript at www.biomedcentral.com/submit 